\title{
Using multimedia-based materials in teaching speaking to elementary school students in Kabanjahe
}

\author{
Rudy Sofyan $^{1^{*}}$, Bahagia Tarigan ${ }^{1}$ \\ ${ }^{1}$ Department of Linguistics, Faculty of Cultural Sciences, Universitas Sumatera Utara \\ *Email: rudy@usu.ac.id
}

\begin{abstract}
As the skill that usually becomes the reference of students' success in learning English, teaching speaking needs to be given closer attention, especially in teaching English to elementary school students. Therefore, a careful choice of good approach, technique or media is required. This article aims at finding out the advantages of using multimedia-based teaching materials in teaching speaking to elementary school students in Kabanjahe, North Sumatra. This is a descriptive study taking the fifth year elementary schools students at SD Swasta Masehi in Kabanjahe of Karo Regency as the participants. The data were collected using observations and interviews. The data were analyzed qualitatively. The results of the study show that using multimedia-based materials benefits the speaking learning process in terms of increasing the students' interest, reducing the students' shyness, increasing students' motivation, and promoting student-centered learning. It is concluded that using multimedia-based materials helps build elementary school students' speaking ability.
\end{abstract}

Keywords: elementary school students, multimedia-based materials, speaking skills, teaching English.

\section{INTRODUCTION}

Considering its role as the language of science and technology (Ferguson, 2007; Drubin \& Kellogg, 2012; Englander, 2014; Foyewa, 2015), English is formally taught at schools in most of the parts of the world, including in Indonesia. English had been the compulsory subject at every level of formal education in Indonesia (from elementary schools up to universities) before the issuance of the 2013 curriculum, the latest applicable curriculum in Indonesia. In the 2013 curriculum, despite the pros and cons of its elimination (Maili, 2018), English is no longer mentioned as the compulsory subject at elementary schools. Nevertheless, several elementary schools insist to include English in their curriculum as a local content subject (Iskandar, 2015; Kaltsum, 2016). The decision to keep teaching English as a local content subject is mainly motivated by the results of many studies finding that learning a foreign language, e.g. English, at earlier ages is effective (Shin, 2010; Gawi, 2012; de Bot, 2014). Moreover, one of the studies suggests learning a foreign language to begin since preschool age (Adzija \& Sindik, 2014). Rapid development of children's basic communication abilities in English and native-like pronunciation, encouragement of enjoyment, motivation, and development of their cognitive skills and metalinguistic awareness are several benefits of learning English at early ages (Pinter, 2006).

Teaching English at elementary schools should emphasize on oral skills, i.e. speaking (Test, Cunningham, \& Lee, 2010; Tinsley \& Comfort, 2012). Considering English as a foreign language in Indonesia, teaching speaking is considered difficult because it requires the students to learn and master pronunciation, structure, and the social context of culture and situation (Rahmadevi \& Rosa, 2012). Therefore, many studies have been conducted on teaching speaking at elementary schools, focusing on the instructional media in teaching speaking (Rahmadevi \& Rosa, 2012; Christamia, 2014; Sofyan, Sinar, Tarigan, \& Zein, 2018), teaching speaking method (Faridi, 2010; Fitria, 2013; Lathufirdaush, 2013; Yanuartin, 2014), and material development for teaching speaking (Safitri, 2010; Mubar, 2015). However, the media used in the previous studies refer to mono media or one kind of media. Meanwhile, in this advanced technology era, mono media is no longer interesting, and the use of multimedia is much more preferred. 
Rudi Sofyan, et.al. Using multimedia-based materials

Multimedia is a combination of two types of information presentation, verbal and visual (Mayer, 2001), or more different information media within a computer system (Babiker, 2015). Also, other scholars define multimedia as the combination of at least two input or output media of data, such as audio (sound and music), animation, video, text, graphics and images (Turban et al., 2002). Moreover, Vaughan (2011) defines multimedia as a combination of digitally manipulated text, photographs, graphic art, sound, animation, and video elements. Thus, multimedia can be defined as the combination of different media using a computer system that is very useful in presentations, such as in teaching.

The importance of speaking for elementary school students and the sophisticated facilities provided through the use of multimedia elaborated in the previous paragraph suggests the important use of multimedia in teaching speaking to elementary school students. However, in certain places, particularly those located in villages, facilities become the barriers to use multimedia-based materials in teaching speaking. Therefore, the benefits offered by the use of multimedia-based materials in learning speaking in the classroom cannot be experienced by both the students and the teachers. Implementing multimedia-based materials certainly needs certain devices such as desktops or laptops and projectors.

This paper aims at finding out the use of multimedia-based materials in teaching speaking to elementary school students in Kabanjahe, North Sumatra.

\section{METHOD}

This study used a descriptive method taking the private elementary school (SD Swasta Masehi) in Kabanjahe of Karo Regency as the research location. This school was chosen because it was the elementary school that continued including English as one of the local contents in its curriculum. The participants were the fifth year elementary school students of SD Swasta Masehi who were taught speaking English by using multimedia-based materials. Three videos downloaded from YouTube channel were designed as the materials presented to the students. The data were collected using observations and interviews. The data were analyzed qualitatively to describe the advantages of using multimedia-based materials in teaching speaking.

\section{DISCUSSION}

The multi-media based materials designed are composed of three videos. The first two videos are used as the presentation materials, while the other video is used for the students' exercises. During the teacher's presentation, the video is used as the model containing the examples of English conversations that contain the expressions as close as possible to the students' daily conversation. "Good morning.", "What's your name?", "How are you?", and "See you" are some expressions presented in the videos. In addition, the video does not only contain images and sounds but also the written expressions spoken by the characters in the video. Figure 1 below is one of the examples of the extract from the video.

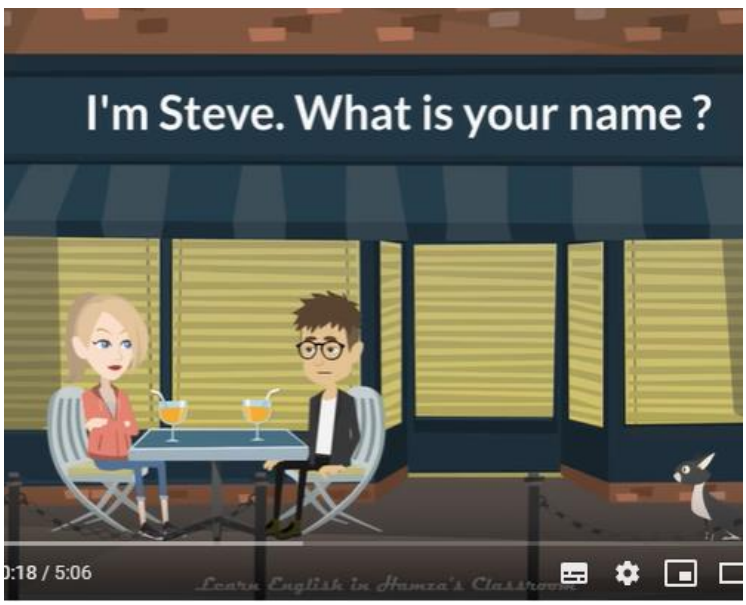

Figure 1. Asking someone's name

Source: https://www.youtube.com/watch?v=oBfyR4J2Xj8 
Figure 1 shows two people having a conversation. The written expression on the screen "I'm Steve. What's your name?" is very helpful to help the students identify what the speakers say. So, in addition, to listening to the speakers' voices and watching their non-verbal expressions, the students can also know their expressions in a written form. The questions and their responses together with the non-verbal expressions shown in the video help the students understand the meaning and the situational context where those expressions are used.

Unlike the implementation of grammar-based teaching where grammar is used as the base (Azar, 2007), using this multimedia-based material does not require the students to pay a lot of attentions to the grammar. This is very good to implement in teaching speaking since the purpose of teaching speaking is to make the students be able to speak (Adhikari, 2010). Nevertheless, this does not mean that grammar is not important in speaking. Grammar is important, but the students should not be much exposed to grammar at the beginning of learning speaking in a foreign language because this will hinder their fluency in speaking.

Moreover, the students can also learn from the video that in English culture, a person has to tell his/her name earlier before he/she asks his/her friend's name. Introducing English culture to the students is important in building their English ability since learning a foreign language (e.g. English) also means learning English culture. Another example of the extract from the video can be seen in Figure 2.

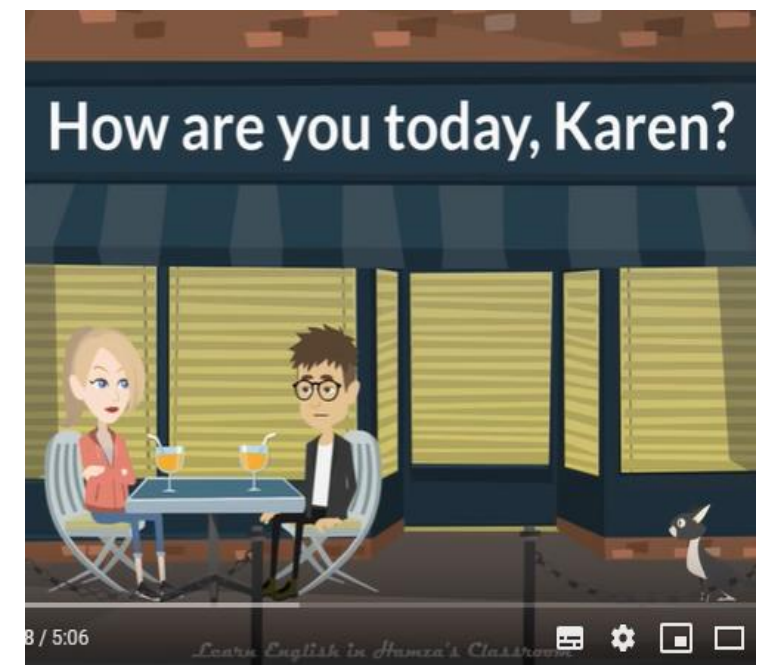

Figure 2. Greetings "How are you?

Source: https://www.youtube.com/watch?v=oBfyR4J2Xj8

Figure 2 is the extract from the video showing example of the greeting which is commonly used in daily interaction, i.e. "How are you?". The video is paused after each of the expressions uttered by the speakers to give the students a chance to imitate their expressions. This means that the teacher can use a drilling technique to make the students familiar and habitual to pronounce those expressions. The teacher is encouraged not to translate every expression uttered by the characters in the video. The students are allowed to understand the meaning of those expressions by themselves by paying attention to the questions and responses provided in the video. Furthermore, the students are asked to practice the conversations in pairs.

After the two videos are presented, then the students are given exercises, which are also designed in the form of multimedia. The speaker in the video asks the questions concerning a basic conversation that has been taught to the students, and the students answer those questions orally. The example of video extract containing the exercise from the speaker in the video can be seen in Figure 3. 


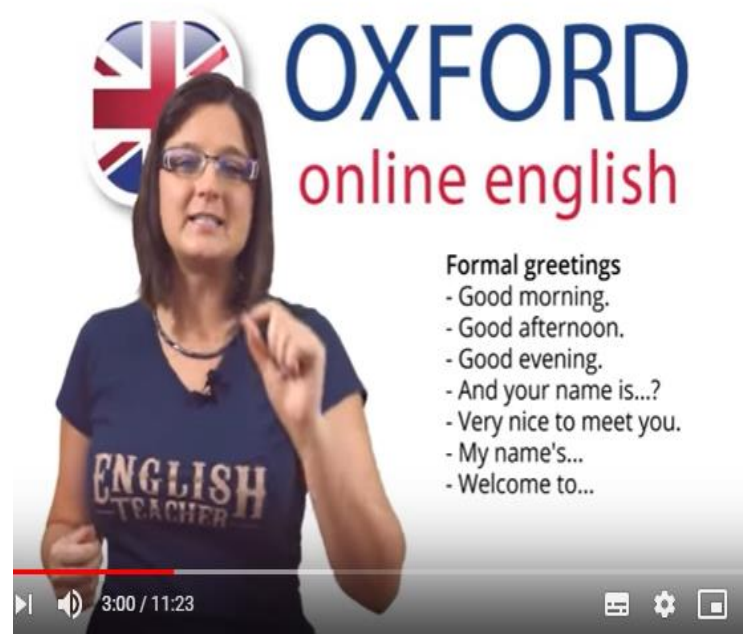

Figure 3. The example of exercise from the video

Source: https://www.youtube.com/watch?v=sp3xU5WvRjA

The speaker in the video asks the questions, and at every question, the video is paused to give the time for the students to answer the questions. For example, when the speaker says "Good morning", then the teacher asks one of the students to give a response to it. The exercise completes when all of the students have already got their turn of answering the questions from the speaker in the video. After doing the exercises based on the given video, the students are asked to do exercises in pairs. They are assigned to practice all of the expressions they have learned.

Based on the results of the observations and interviews with the students, the use of multimedia-based materials benefits the process of teaching speaking to elementary school students at SD Swasta Masehi Kabanjahe. The first advantage is increasing the students' interest in learning speaking English. During the learning process, the students look very enthusiastic, they focus on the video played by the teacher. So, they do not only listen to their teachers, but they also watch and listen to the conversations performed by English native speakers. This finding is quite logical since their teachers never played any videos while teaching speaking. Based on the interviews with several students, some of their English teachers only gave them an example of conversation and read it while asking the students to repeat. Some of the teachers used pictures as the media and asked the students to make a conversation based on the pictures. These techniques usually end in less useful expressions since what the students learned and practiced at school are not the expressions frequently used in the actual daily conversations.

This finding supports the result of the research done by Suryani and Rosa (2014) who argue that students' interest and enthusiasm is very important in building the early speaking ability of young learners. Besides, Muna (2011) also argues that the use of video as the teaching media increases the students' interest in speaking because it changes the monotonous classroom atmosphere into an interactive one. Their findings strongly suggest the important role of students' interest and enthusiasm in building their speaking skill.

The other advantage of using multimedia-based materials in teaching speaking is reducing the students' shyness. One of the major problems in teaching speaking is shyness (e.g. Juhana, 2012; Kurniawan \& Rosa, 2013; Namaghi, Safaee, \& Sobhanifar, 2015), and many students feel shy to speak worrying that they will be laughed at by their classmates. Namaghi et al. (2015) report that shyness makes students less likely to initiate interactions with others. However, by using these multimedia-based materials, all of the students enjoy the class and they never realize that they speak English because they are enthusiastic to follow the expressions modeled by the speakers in the videos. They do not feel shy either to initiate the conversation or to give responses by using English. Shyness, one of the factors hindering the students from speaking (Juhana, 2012), is much motivated by anxiety (Namaghi et al., 2015), and these multimedia-based learning materials lose such anxiety; as a result, the students are courageous to speak. At the same time, reducing shyness also increases 
Rudi Sofyan, et.al. Using multimedia-based materials

the students' self-confidence in speaking as they can reduce their fear of making mistakes while speaking.

The next advantage is increasing the students' motivation. The students seem impatient to wait for their turn to answer the questions provided in the videos. As mentioned earlier, all of the students have the same opportunity to speak based on the order of the questions provided in the videos. None of them keeps silent when the questions are addressed to them. Such motivation is also visible during pair work. All of them participate actively asking and answering the questions. Several studies have proved that motivation is the key success of learning English (e.g. Juhana, 2012; Kurniawan \& Rosa, 2013; Namaghi et al., 2015; Sofyan et al. 2018).

The last advantage is promoting student-centered learning. By using these multimedia-based learning materials, the teacher acts as the facilitator as well as the motivator, not the center of learning. The teacher facilitates the learning media and motivates the students to reduce any psychological factors that might hinder them from being the courage to perform their English orally. Meanwhile, all of the learning activities are central to the students as they watch a video, imitating the speakers' expressions, and practicing the conversations in pairs. This is corresponding to the nature of teaching speaking, i.e. to make the students active in speaking.

\section{CONCLUSIONS AND SUGGESTIONS}

Based on the discussion on using multimedia-based materials in teaching speaking, it is concluded that multimedia-based materials provide some advantages, such as increasing the students' interest, reducing the students' shyness, increasing students' motivation, and promoting student-centered learning.

This study only focuses on videos, other multimedia-based materials are also possible to be used and studied by other researchers. As they benefit the learning process of speaking, it is suggested for teachers, especially those teaching English to young learners, to use these multimedia-based materials in teaching speaking.

\section{ACKNOWLEDGMENTS}

The authors would like to thank the Community Service Institute of Universitas Sumatera Utara for funding this community service project under the Program Pengabdian Kepada Masyarakat Mono Tahun TALENTA 2019 Grant.

\section{REFERENCES}

Adhikari, B. R. 2010. Teaching speaking in the Nepalese context: Problems and ways of overcoming them. Journal of NELTA, 15(1-2), 1-9.

Adzija, M. \& Sindik, J. 2014. Learning of foreign language in pre-school children: Evaluation methods in kindergarten's environment. Metodički obzori, 9(19), 48-65.

Azar, B. 2007. Grammar-based teaching: A practitioner's perspective. TESL-EJ, 11(2), 1-12.

Babiker, M. E. A. 2015. For effective use of multimedia in education, teachers must develop their own educational multimedia applications. TOJET: The Turkish Online Journal of Educational Technology, 14(4), 62-68.

de Bot, K. 2014. The effectiveness of early foreign language learning in the Netherlands. Studies in Second Language Learning and Teaching, 4(3), 409-418.

Christamia, V. 2014. Improving students' speaking skills through English songs and puppets at Grade IV of SD N Adisucipto II in the academic year of 2013/2014. Thesis. Yogyakarta: Universitas Negeri Yogyakarta.

Drubin, D. G. \& Kellogg, D. R. 2012. English as the universal language of science: Opportunities and challenges. Molecular Biology of the Cell, 23, 1399.

Englander, K. 2014. The rise of English as the language of science. In: Writing and publishing science research papers in English: A global perspective. Dordrecht: Springer.

Faridi, A. 2010. The development of context-based English learning resources for elementary schools in Central Java. Excellence in Higher Education, 1(2010), 23-30. 
Rudi Sofyan, et.al. Using multimedia-based materials

Ferguson, G. 2007. The global spread of English, scientific communication and ESP: Questions of equity, access and domain loss. IBÉRICA, 13, 7-38.

Fitria, S. 2013. Speaking activities in young learners classroom: The implementation of projectbased learning approach. Journal of English and Education, 1(2), 90-102.

Foyewa, R. A. 2015. English: The international language of science and technology. International Journal of English Language and Linguistics Research, 3(5), 34-41.

Gawi, E. M. K. 2012. The effects of age factor on learning English: A case study of learning English in Saudi Schools, Saudi Arabia. English Language Teaching, 5(1), 127-139.

Iskandar, I. 2015. Putting English as a local content subject in primary schools: Teachers' belief and its impact on their teaching delivery. Proceedings of the 62nd TEFLIN International Conference, pp. 1-10.

Juhana 2012. Psychological factors that hinder students from speaking in English class (A case study in a senior high school in South Tangerang, Banten, Indonesia). Journal of Education and Practice, 3(12), 100-110.

Kaltsum, H. U. 2016. Bahasa Inggris dalam Kurikulum 2013 di sekolah dasar. Proceedings of the 3rd University Research Colloquium, pp. 276-283.

Kurniawan, C. \& Rosa, R. N. 2013. Using tourism brochure pictures to generate ideas in improving junior high school student's speaking ability. Journal of English Language Teaching, 1(2), 399-408.

Lathufirdaush, F. 2013. The implementation of theme-based teaching to improve students' speaking skill. Thesis, Bandung: Universitas Pendidikan Indonesia.

Maili, S. N. 2018. Bahasa Inggris pada sekolah dasar: Mengapa perlu dan mengapa dipersoalkan. Judika ((Jurnal Pendidikan Unsika), 6(1), 23-28.

Mayer, R. E. 2001. Multimedia learning. New York: Cambridge University Press.

Mubar, M. K. N. A. 2015. Developing English learning materials for young learners based on needs analysis at MTSN Model Makassar. ETERNAL, 1(2), 313-330.

Muna, M. S. 2011. Utilizing YouTube videos to enhance students' speaking skill. Thesis. Surakarta: Universitas Sebelas Maret.

Namaghi, S. A. O., Safaee, S. E., \& Sobhanifar, A. 2015. The effect of shyness on English speaking scores of Iranian EFL learners. Journal of Literature, Languages and Linguistics, 12(2015), $22-27$.

Pinter, A. 2006. Teaching young languge learners. Oxford: Oxford University Press.

Rahmadevi, Y. \& Rosa, R. N. 2012. Using everyday life posters in teaching speaking to elementary school students. Journal of English Language Teaching, 1(1), 182-188.

Safitri, A. Y. 2010. Designing a set of English speaking materials for the extracurricular activities using cooperative learning activities for $6^{\text {th }}$ Grade students of SD Percobaan PAKEM. Thesis. Yogyakarta: Universitas Sanat Dharma.

Shin, S. J. 2010. Teaching English language learners: Recommendations for early childhood educators. Dimensions of Early Childhood, 38(2), 13-21.

Sofyan, R., Sinar, T. S., Tarigan, B., \& Zein, T. T. 2018. Using a "snake and ladder" game in teaching speaking to young learners. ABDIMAS TALENTA, 3(2), 226-231.

Suryani, A. \& Rosa, R. N. 2014. Using a board game "snake and ladder" in teaching speaking at junior high school. Journal of English Language Teaching, 2(2), 16-24.

Test, J. E., Cunningham, D. D., \& Lee, A. C. 2010. Talking with young children: How teachers encourage learning. Dimensions of Early Childhood, 38(3), 3-14.

Tinsley, T. \& Comfort, T. 2012. Lessons from abroad: International review of primary languages. Research report. CfBT Education Trust. Available at https://www.educationdevelopmenttrust.com/ /media/EDT/Reports/Research/2012/rlessons-from-abroad-2012.pdf.

Turban, E., King, D., Lee, J., Warkentin, M., \& Chung, H. 2002. Electronic commerce: A managerial perspective. New Jersey: Prentice Hall.

Vaughan, T. 2011. Multimedia: Making it works. $8^{\text {th }}$ Edition. New York: McGraw Hill, 
ISSN Printed Version: 2549-4341

ISSN Online Version: 2549-418X

ABDIMAS TALENTA 4 (2) 2019: 692 - 698

http://abdimas.usu.ac.id

Rudi Sofyan, et.al. Using multimedia-based materials

Yanuartin, D. S. T. 2014. Improving student's speaking skill of the $4^{\text {th }}$ Grade students of SD Negeri 1 Sewon in the academic year of 2013/2014 through role-play activities. Thesis. Yogyakarta: Universitas Negeri Yogyakarta. 